\title{
Lead, mercury and cadmium content in bottom sediments, reed (Phragmites australis) beds and great pond snails (Lymnaea stagnalis) in fishponds and the role of littoral zones in their accumulation
}

\author{
Jan Sychra ${ }^{1}$, Olga Čelechovská ${ }^{2}$ Zdeňka Svobodová ${ }^{3}$,Oldřich Sychra ${ }^{4}$ \\ ${ }^{1}$ Department of Botany and Zoology, Faculty of Science, Masaryk University, Brno, Czech Republic \\ ${ }^{2}$ Department of Biochemistry, Chemistry and Biophysics, ${ }^{3}$ Department of Veterinary Public Health and \\ Toxicology, ${ }^{4}$ Department of Biology and Wildlife Diseases, Faculty of Veterinary Hygiene and Ecology, \\ University of Veterinary and Pharmaceutical Sciences, Brno, Czech Republic
}

Received September 15, 2010

Accepted April 6, 2011

\begin{abstract}
We studied the contents of cadmium $(\mathrm{Cd})$, lead $(\mathrm{Pb})$ and mercury $(\mathrm{Hg})$ in common reed (Phragmites australis), great pond snails (Lymnaea stagnalis), and in littoral bottom sediments in 18 fishponds in two regions of the Czech Republic. We also assessed the impact of environmental factors on heavy metal accumulation in these three components of littoral ecosystem. Cadmium and lead values were significantly higher in bottom sediments (median values 0.70 and 13.4 $\left.\mathrm{mg} \cdot \mathrm{kg}^{-1}\right)$ than in reed $\left(0.014\right.$ and $\left.0.51 \mathrm{mg} \cdot \mathrm{kg}^{-1}\right)$ and snails $\left(0.074\right.$ and $\left.0.81 \mathrm{mg} \cdot \mathrm{kg}^{-1}\right)$. Cadmium values in reed stems positively correlated with $\mathrm{Cd}$ values in great pond snails (Spearman's rank correlation, $\left.\mathrm{r}_{\mathrm{s}}=0.62 ; p<0.05\right)$. Cadmium and lead contents in reed stems positively correlated with each other $\left(\mathrm{r}_{\mathrm{s}}=0.56 ; p<0.05\right)$. The mercury values in snails $\left(0.043 \mathrm{mg} \cdot \mathrm{kg}^{-1}\right)$ were higher than in sediments $\left(0.040 \mathrm{mg} \cdot \mathrm{kg}^{-1}\right)$ and these were higher than in reed stems $\left(0.010 \mathrm{mg} \cdot \mathrm{kg}^{-1}\right)$. We also found higher mercury contents in reed stems and higher cadmium contents in great pond snails in eastern compared to western parts of investigated ponds. Based on the principal component analysis (PCA) performed on heavy metal values, relative reed beds rate in the pond perimeter was negatively correlated with the sample scores on the first PCA axis and the orientation of sampling site and fish stock density negatively correlated with the second PCA axis. Our results proved the important role of littoral sediments in $\mathrm{Cd}, \mathrm{Pb}$ and $\mathrm{Hg}$ accumulation, and the suitability of great pond snails for mercury stress biomonitoring in fishponds. In conclusion, littoral reed beds play a very important role in toxic element uptake in fishponds. The results contribute to the understanding of heavy metal cycles and their accumulation in fishponds under semi-natural conditions and in less affected landscape, and can be used as reference values for comparison with more damaged sites.
\end{abstract}

Fishpond littoral, heavy metals, environmental factors

The increase in heavy metal concentrations in the environment in the last decades is primarily due to erosion and anthropogenic activities, and because metals are very persistent pollutants, they accumulate in the soil, water sediments and in the food chain (Čelechovská et al. 2008). Wetlands and other aquatic habitats play an important role in heavy metals uptake, transport and accumulation in landscape (Jackson 1998). Especially vegetated littoral zones of water bodies can serve both as metals sinks and sources (Lakatos et al. 1999; Bragato et al. 2006). However, higher heavy metals' input to wetlands can cause serious changes in the natural ecosystem functioning, such as changes in the food chain structure, physiological and behavioral changes in aquatic organisms as well as decrease of biodiversity and extinction of sensitive taxa (Pip 2006; Bogatov and Bogatova 2009; Bonanno and Lo Giudice 2010).

In this respect, bottom sediments, aquatic macrophytes and invertebrates are very important links in metal cycles in the aquatic environment and they are commonly used in the biomonitoring of heavy metals. Generally, sediments can accumulate large amounts of heavy metals and become their main reservoir in the wetlands (Svobodová et al. 2002).

Address for correspondence:

Mgr. Jan Sychra

Department of Botany and Zoology

Faculty of Science

Masaryk University

Kotlářská 2, 61137 Brno, Czech Republic

Phone: + 420532146342

E-mail: dubovec@seznam.cz

http://www.vfu.cz/acta-vet/actavet.htm 
Littoral helophyte beds, such as widely distributed beds of common reed (Phragmites australis (Cav.) Steud.) or cattails (Typha spp.), serve as the main pathway of metal transfer from sediments and water to higher trophic levels (Jackson 1998) and can largely influence metal retention in littorals, which is recently used in wetlands constructed for polluted or waste water treatment (Salt et al. 1995; Vymazal et al. 2009). The functioning of macrophyte beds in connection with toxic contaminants in aquatic ecosystems is studied by many authors (Jackson 1998; Szymanowska et al. 1999; Bragato et al. 2006; Bonanno and Lo Giudice 2010).

Metal uptake pattern of aquatic macroinvertebrates is comparatively less known. Due to their often broad distribution and great abundances in both terrestrial and aquatic environments, their limited mobility and relative great accumulation potency for contaminants, molluscs - both snails (Gastropoda) and mussels (Bivalvia) are suitable indicators of toxic matters in aquatic habitats and for that reason are commonly studied around the world from the ecotoxicological point of view (Elder and Collins 1991). Among them, great pond snail (Lymnaea stagnalis L.), which is one of the most common snails of freshwater habitats in central Europe, have a good indicator potential, since more information about the features of heavy metal accumulation, toxic pollution tolerance and impact of metals on the physiology of the genus Lymnaea are known (Królak 1998; Bogatov and Bogatova 2009).

Despite many present studies, little is known about the metals cycles and roles of particular components of wetland ecosystems in their transport and accumulation in littorals of standing waters under natural conditions. Fishponds, which are a common aquatic habitat in the Czech Republic, are very suitable for this type of research, because of their semi-natural character and relatively good controllability of element supply and release.

The aim of this study was to find how the contents of selected higher toxic metals cadmium, lead and mercury differ in common littoral organisms, common reed and great pond snail, and in bottom sediments, and to evaluate the impact of environmental factors on heavy metal accumulation in littoral zones of 18 fishponds in the south-eastern part of the Czech Republic.

\section{Materials and Methods}

The research was performed during the period from June to August 2006 in 18 fishponds in two regions of the Czech Republic (Fig. 1). Nine of the sampled fishponds were situated near the town of Náměšt' n. Oslavou in the south-eastern part of the Czech-Moravian Highlands (approx. 49.30N, 16.01E), 390-460 m above sea level. It was a system of mostly smaller fishponds supplied with water exclusively from precipitations, with the area of up to 26 ha. The second study site was conducted in southern Moravia (approx. 48.52N, 16.35E), with the elevation of about 150-200 m and with mainly hot and dry climate. Most of these nine ponds were on watercourse and their size was mostly larger; it ranged between 5.5 and 290 ha. For detailed information on the characteristics of ponds see Table 1. During the sampling period, common carp (Cyprinus carpio L.) prevailed in the fish stock released in all investigated fishponds. In south Moravian fishponds also grass carp (Ctenopharyngodon idella Val.), silver carp (Hypophthalmichthys molitrix Val.), bighead carp (Aristichthys nobilis Rich.), zander (Sander lucioperca L.), tench (Tinca tinca L.) and other fish were present in fish stock. Because of semi-intensive fish farming and frequent usage of manure for pond fertilization, fishponds were generally highly eutrophic. Reed and cattail beds were the most common vegetation type in littoral zones at sampling sites.

In larger reed beds of each investigated pond, 3 specimens of the great pond snail and samples of about 5 reed stems from different parts of littoral zone were collected. The upper layer of about $10 \times 10 \times 10 \mathrm{~cm}$ of the bottom sediments was collected by hands from five various parts of the littoral near the reed beds in the open water zone and a pooled sample was elaborated. Samples of snails, reed and sediments were placed in microtene bags and were kept at $-18{ }^{\circ} \mathrm{C}$ until analyses were carried out.

Determination of the total mercury content in all samples (tissues and sediments) was performed by means of atomic absorption spectrophotometric (AAS) method using a single-purpose cold vapor mercury analyzer AMA-254 (ALTEC Ltd., Czech Republic). Prior to analysis, samples of sediment and reed were desiccated at $60{ }^{\circ} \mathrm{C}$ and homogenized. Method validation was performed by means of the reference standard sample CRM 


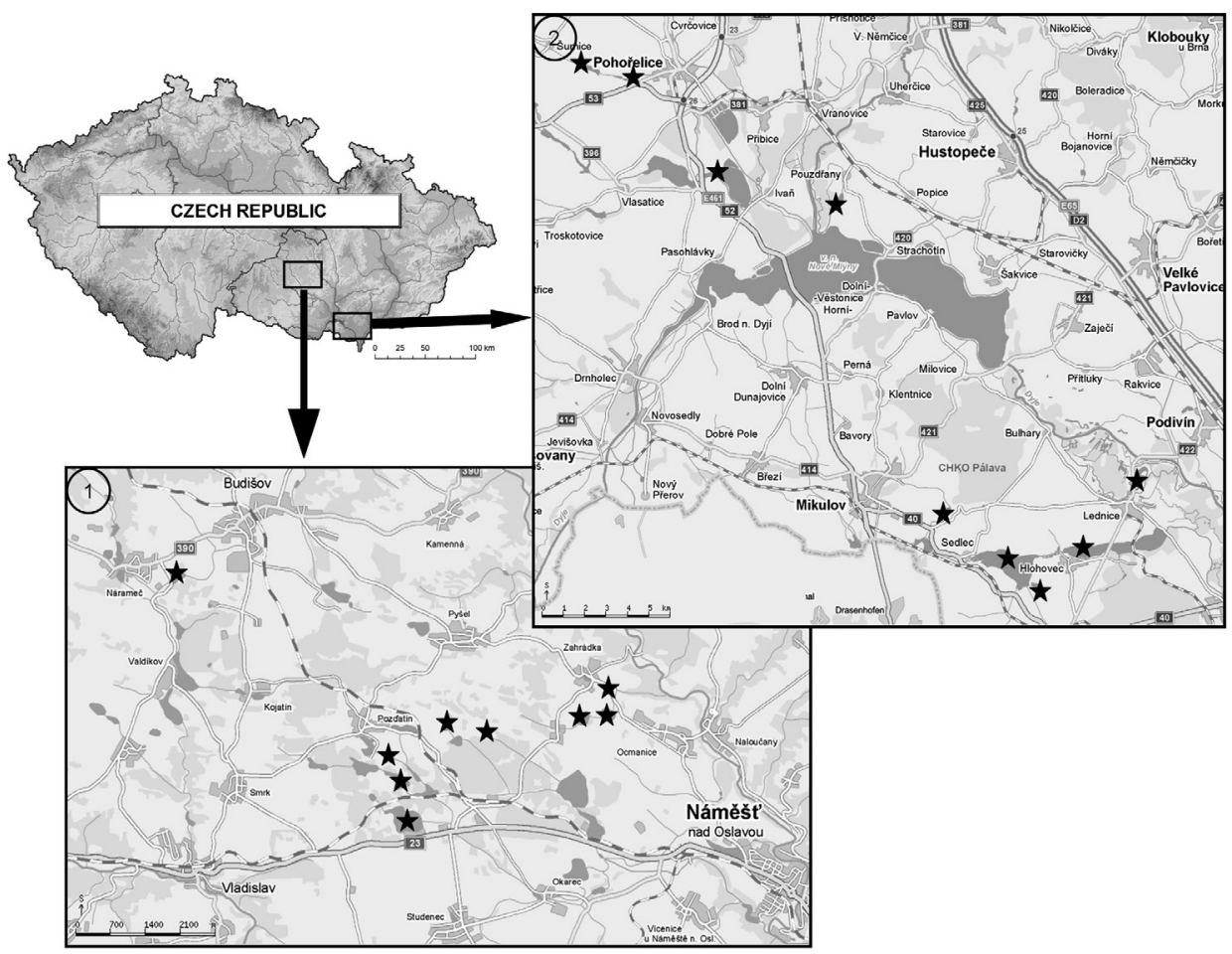

Fig. 1. Location of study sites: 1 - south-eastern margin of the Czech-Moravian Highlands, 2 - Southern Moravia; sampling fishponds are marked by black asterisks (www.mapy.cz)

016-050 - sediment (RTC, USA), KS 1 - sediment (ČIA, Czech Republic) and SRM 1575 - Pine needles (NIST, USA). The sample was then dried at $100{ }^{\circ} \mathrm{C}$ and results were re-counted on dry matter.

Preparation of bottom sediment samples for the determination of cadmium $(\mathrm{Cd})$ and lead $(\mathrm{Pb})$ followed ISO 11466 standard using aqua regia. Determination was performed by AAS flame technique (ZEEnit 700, Analytika Jena, Germany). Prior to the cadmium and lead determination in tissues by electrothermal AAS, samples were mineralized using nitrogen acid and hydrogen peroxide in laboratory autoclaves with microwave heating (ETHOS SEL, Milestone, Italy).

Samples of great pond snails were homogenized and determination of the contents all the studied metals was performed in native tissue and then re-counted on dry matter. Method validation was performed by means of the standard reference material CRM 278 - mussel tissue and CRM 184 - bovine muscle (BCR, Belgium). Detection limits $(3 \sigma)$ were: $\mathrm{Pb} 0.05 \mathrm{mg} \cdot \mathrm{kg}^{-1}, \mathrm{Cd} 2 \mu \mathrm{g} \cdot \mathrm{kg}^{-1}$ (for ET AAS) and $\mathrm{Hg} 0.01 \mathrm{ng}$ (for AMA analyzer).

Environmental characteristics of all fishponds, sampling sites and their surroundings (total fishpond area, reed beds area, rate of woods, fields and meadows in pond surroundings, orientation of sampling site - eastern or western part of a pond) were recorded using the ArcMap software (version 9.3; ESRI Inc. 2008). The data on fish stock were provided by fish farmers (Rybářství Velké Meziříčí a. s. and Rybníkářství Pohořelice a. s.).

Recorded values of heavy metal concentrations were analyzed for differences in bottom sediments, reed stems and great pond snails using Kruskal-Wallis ANOVA and for correlations between these values using Spearman's rank correlation $\left(r_{s}\right)$. For determination of differences between metal contents in unlikely orientated littorals Mann-Whitney U Test was used. Principal component analysis (PCA) was employed to identify the most important gradients in the data on heavy metal contents. The data were centered and standardized prior to the analysis to reduce the effect of different scales. To interpret main gradients in the species data the sample scores on the first four PCA axes were correlated (Spearman's rank correlation, $\mathrm{r}_{\mathrm{S}}$ ) with environmental parameters. Both analyses and graphs were performed in softwares Statistica (version 8.0; StatSoft Inc. 2008) and Canoco for Windows (version 4.5; ter Braak and Šmilauer 2002). All results were considered as significant at $p<0.05$. 
Table 1. The main characteristics of investigated ponds and their surroundings.

\begin{tabular}{|c|c|c|c|c|c|c|c|c|c|c|}
\hline Fishpond & Region $^{1}$ & Area (ha) & $\begin{array}{l}\text { Reed beds } \\
\text { area (ha) }\end{array}$ & $\begin{array}{l}\text { Woods } \\
(\%)^{2}\end{array}$ & $\begin{array}{l}\text { Fields } \\
(\%)^{2}\end{array}$ & $\begin{array}{c}\text { Meadows } \\
(\%)^{2}\end{array}$ & $\begin{array}{c}\text { Motorways } \\
(\%)^{2}\end{array}$ & $\begin{array}{l}\text { Location in } \\
\text { pond }^{3}\end{array}$ & $\begin{array}{c}\text { Fish stock } \\
\text { density } \\
\left(\mathrm{t} \cdot \mathrm{ha}^{-1}\right)\end{array}$ & $\begin{array}{c}\text { Carp stock } \\
\text { age } \\
\text { (years) }\end{array}$ \\
\hline Čepička & $\mathrm{CMH}$ & 2.50 & 0.14 & 45 & 0 & 55 & 0 & W & 0.14 & 1 \\
\hline Hranečník & $\mathrm{CMH}$ & 4.40 & 0.76 & 66.8 & 0 & 33.2 & 0 & NW & 0.27 & 1 \\
\hline Myšník & $\mathrm{CMH}$ & 6.80 & 0.38 & 0 & 61.1 & 38.9 & 0 & SW & 0.53 & 1 \\
\hline Nohavice & $\mathrm{CMH}$ & 1.80 & 0.10 & 8.2 & 34 & 13.2 & 44.6 & $\mathrm{NE}$ & 0.67 & 3 \\
\hline Nový Častotický & $\mathrm{CMH}$ & 5.20 & 0.48 & 18.7 & 54.1 & 27.2 & 0 & SE & 0.26 & 1 \\
\hline Nový Studenecký & $\mathrm{CMH}$ & 26.00 & 0.54 & 41.6 & 39.8 & 18.6 & 0 & $\mathrm{NE}$ & 0.57 & 2 \\
\hline Stračínek & $\mathrm{CMH}$ & 3.38 & 0.69 & 0 & 35.1 & 40.7 & 24.2 & W & 0.71 & 0 \\
\hline Štíčí & $\mathrm{CMH}$ & 1.20 & 0.20 & 37.5 & 62.5 & 0 & 0 & $\mathrm{NE}$ & 0.56 & 2 \\
\hline Vrbinec & $\mathrm{CMH}$ & 6.50 & 0.31 & 54 & 46 & 0 & 0 & W & 0.60 & 1 \\
\hline Hlohovecký & SM & 100.18 & 7.25 & 58.7 & 0 & 32.6 & 8.7 & SW & 0.62 & 2 \\
\hline Mušlovský dolní & SM & 5.95 & 0.21 & 59.8 & 9.5 & 20.3 & 10.4 & $\mathrm{SE}$ & 0.29 & 1 \\
\hline Nesyt & SM & 289.67 & 48.06 & 0 & 72.4 & 19.6 & 6.1 & NW & 0.51 & 3 \\
\hline Nohavice & SM & 8.37 & 0.80 & 0 & 49 & 0 & 0 & $\mathrm{NE}$ & 0.29 & 0 \\
\hline Pohořelický & SM & 5.60 & 1.04 & 11.5 & 83.8 & 0 & 0 & SE & 0.59 & 1 \\
\hline Pouzdřanský & SM & 20.97 & 1.58 & 52.2 & 24.5 & 23.3 & 0 & $\mathrm{NE}$ & 0.74 & 1 \\
\hline Šumický horní & SM & 18.34 & 4.74 & 0 & 88.6 & 11.4 & 0 & SE & 0.09 & 0 \\
\hline Výtopa & SM & 7.17 & 0.78 & 0 & 34.5 & 55.3 & 0 & W & 0.27 & 1 \\
\hline Zámecký & SM & 26.50 & 0.60 & 26.9 & 0 & 47.8 & 25.3 & NW & $0.00^{4}$ & - \\
\hline
\end{tabular}

${ }^{1}$ Regions: CMH - Czech-Moravian Highlands, SM - Southern Moravia; ${ }^{2}$ Estimation of relative proportion in fishpond surroundings; ${ }^{3}$ Part of the pond (point of the compass) where sampling was done; ${ }^{4}$ Fishpond without fish stock.

\section{Results}

Cadmium, lead and mercury values varied between reed stems, great pond snails and littoral bottom sediments and also between sampling sites (Table 2). The cadmium and lead values were significantly higher in bottom sediments than in reed and snails (Kruskal-Wallis ANOVA; $p<0.05$ ) and the ranking of these components from the greatest to smallest $\mathrm{Cd}$ and $\mathrm{Pb}$ concentrations was as follows: bottom sediments $>$ great pond snails $>$ reed stems. On the other hand, mercury values in dry matter of snails were equal to or higher than values of $\mathrm{Hg}$ in sediments. Mercury contents in reed stems were significantly lower than in snails and sediments (Table 2).

Although metal content values varied between ponds, differences between the two investigated regions were non-significant (Mann-Whitney $\mathrm{U}$ test; $p>0.05$ ). However, in the Czech-Moravian Highlands slightly higher median values of heavy metals content were recorded in most of cases (Table 2). On the other hand, the highest values of all studied metals in sediments were recorded in Zámecký fishpond in southern Moravia. No significant correlations were found between metal contents in sediments and in studied organisms. Cadmium values in reed positively correlated with Cd values in snails (Spearman's rank correlation, $\left.\mathrm{r}_{\mathrm{S}}=0.62 ; p<0.05\right)$. Cadmium and lead contents in reed stems positively correlated with each other (Spearman's rank correlation, $\mathrm{r}_{\mathrm{s}}=0.56 ; p<0.05$ ). We found differences between heavy metal contents in eastward and westward orientated littorals. Mann-Whitney $U$ test proved higher mercury contents in reed stems and higher cadmium contents in great pond snails in the ponds sampled in eastern parts (Table 1) compared to those sampled in western parts $(p<0.05$; Figs $2-3)$. Although no significant differences were found in the rest of ponds, higher values were mostly found also in eastern parts. 
Table 2. Heavy metal contents in reed stems, great pond snails and bottom sediments in 18 investigated fishponds. All values are in $\mathrm{mg} \cdot \mathrm{kg}^{-1}$ of dry matter.

\begin{tabular}{|c|c|c|c|c|c|c|c|c|c|}
\hline \multirow[t]{2}{*}{ Fishpond } & \multicolumn{2}{|c|}{ Cadmium (Cd) } & \multicolumn{4}{|c|}{ Lead $(\mathrm{Pb})$} & \multicolumn{3}{|c|}{ Mercury (Hg) } \\
\hline & RS & GPS & BS & RS & GPS & BS & RS & GPS & BS \\
\hline Čepička & 0.010 & 0.052 & 0.91 & 0.64 & 0.86 & 21.1 & 0.005 & 0.029 & 0.030 \\
\hline Hranečník & 0.009 & 0.054 & 0.63 & 0.24 & 0.93 & 19.5 & 0.005 & 0.100 & 0.044 \\
\hline Myšník & 0.007 & 0.043 & 0.66 & 0.04 & 0.69 & 19.3 & 0.006 & 0.017 & 0.043 \\
\hline Nohavice & 0.027 & 0.341 & 0.69 & 1.10 & 0.65 & 14.9 & 0.016 & 0.053 & 0.029 \\
\hline Nový Častotický & 0.022 & 0.083 & 0.66 & 0.65 & 1.40 & 14.0 & 0.019 & 0.124 & 0.016 \\
\hline Nový Studenecký & 0.030 & 0.135 & 0.88 & 0.64 & 1.06 & 37.9 & 0.006 & 0.039 & 0.037 \\
\hline Stračínek & 0.029 & 0.238 & 0.89 & 0.08 & 0.95 & 26.6 & 0.022 & 0.089 & 0.048 \\
\hline Štíćí & 0.017 & 0.248 & 0.69 & 0.17 & 0.61 & 12.0 & 0.019 & 0.172 & 0.022 \\
\hline Vrbinec & 0.024 & 0.077 & 0.75 & 0.69 & 0.58 & 12.3 & 0.005 & 0.044 & 0.014 \\
\hline Hlohovecký & 0.009 & 0.025 & 0.64 & 0.38 & 0.52 & 2.52 & 0.007 & 0.033 & 0.019 \\
\hline Mušlovský dolní & 0.006 & 0.117 & 1.42 & 0.05 & 0.87 & 11.1 & 0.013 & 0.027 & 0.075 \\
\hline Nesyt & 0.014 & 0.023 & 0.70 & 1.04 & 0.88 & 6.68 & 0.006 & 0.036 & 0.038 \\
\hline Nohavice & 0.019 & 0.134 & 0.65 & 1.17 & 0.62 & 8.40 & 0.017 & 0.043 & 0.041 \\
\hline Pohořelický & 0.011 & 0.065 & 0.89 & 0.23 & 1.63 & 11.9 & 0.018 & 0.099 & 0.036 \\
\hline Pouzdřanský & 0.037 & 0.231 & 1.32 & 1.15 & 0.87 & 39.4 & 0.013 & 0.026 & 0.179 \\
\hline Šumický horní & 0.009 & 0.072 & 0.70 & 0.15 & 0.51 & 12.9 & 0.026 & 0.095 & 0.041 \\
\hline Výtopa & 0.014 & 0.018 & 0.68 & 1.19 & 0.76 & 10.8 & 0.003 & 0.041 & 0.072 \\
\hline Zámecký & 0.010 & 0.062 & 1.44 & 0.04 & 0.50 & 46.3 & 0.003 & 0.149 & 0.236 \\
\hline C-M Highland ${ }^{1}$ & 0.022 & 0.083 & 0.69 & 0.64 & 0.86 & 19.4 & 0.006 & 0.053 & 0.030 \\
\hline S Moravia $^{2}$ & 0.011 & 0.065 & 0.70 & 0.38 & 0.76 & 11.1 & 0.013 & 0.041 & 0.041 \\
\hline Median value & $0.014^{\mathrm{a}}$ & $0.074^{\mathrm{b}}$ & $0.70^{c}$ & $0.51^{\mathrm{a}}$ & $0.81^{\mathrm{a}}$ & $13.4^{\mathrm{b}}$ & $0.010^{\mathrm{a}}$ & $0.043^{\mathrm{b}}$ & $0.040^{\mathrm{b}}$ \\
\hline
\end{tabular}

${ }^{1}$ Median values of heavy metal contents in the Czech-Moravian Highlands (the first 9 mentioned ponds);

${ }^{2}$ Median values of heavy metal contents in Southern Moravia (the last 9 mentioned ponds). RS = reed stems; GPS $=$ great pond snails; BS $=$ bottom sediments. Different letters in the last row indicate significant $(p<0.05)$ differences based on Kruskal-Wallis Anova within studied components for each heavy metal.

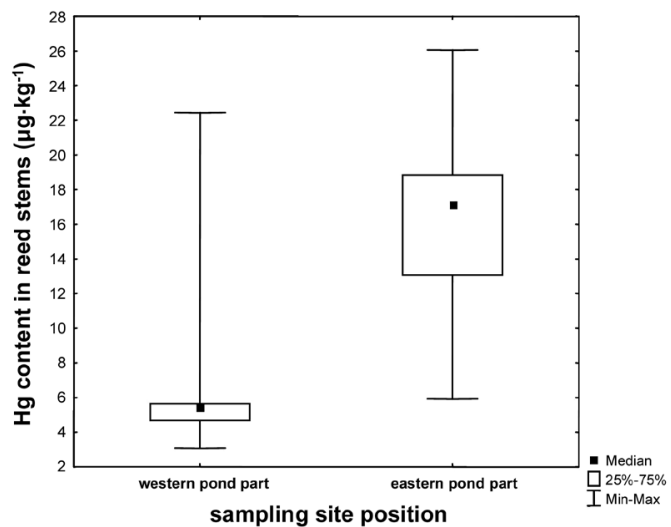

Fig. 2. Mercury contents in reed stems in differently positioned sampling sites (Mann-Whitney $\mathrm{U}$ test; $p<0.05$; $\mathrm{n}=18$ )

Direct impact of other monitored environmental conditions on heavy metals contents in investigated ponds was not proved. The first axis of PCA based on heavy metal contents explained $29.3 \%$ and second one $23.1 \%$ of the total variance. The relative reed beds rate in 


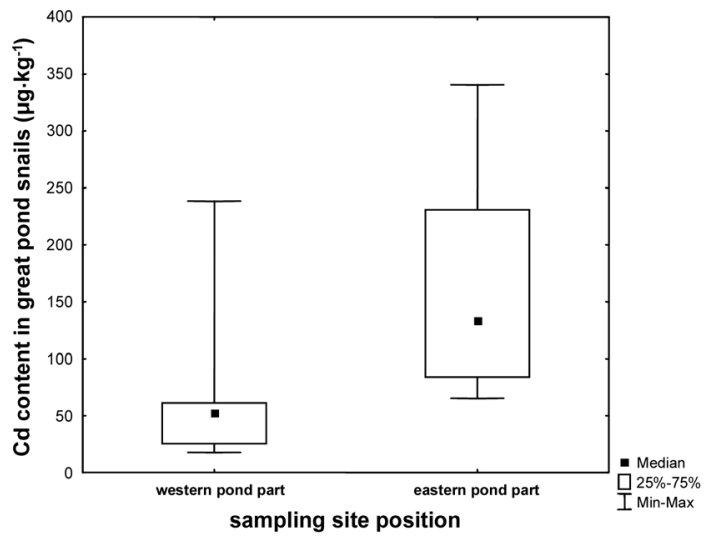

Fig. 3. Cadmium contents in great pond snails in differently positioned sampling sites (Mann-Whitney U test; $p<0.05 ; \mathrm{n}=18)$

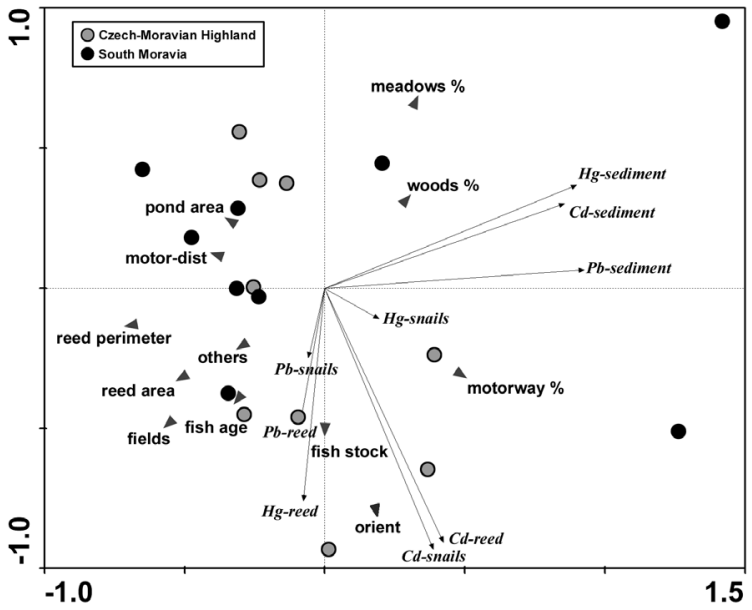

Fig. 4. Principal component analysis ordination plot with sampled ponds, heavy metal contents and environmental characteristics. First and second principal components are displayed.

the pond perimeter negatively correlated with the sample scores on the first PCA axis and the orientation of sampling site and fish stock density negatively correlated with the second PCA axis (Fig. 4).

\section{Discussion}

Cadmium, lead and mercury are highly toxic heavy metals that frequently enter various water bodies in connection with agriculture procedures (especially by use of special fertilizers) and/or motorway traffic in their surroundings (Svobodová et al. 1996) and can cause serious damages in these ecosystems. The values of these metals recorded in sediments and reed stems at 18 fishponds during this study were comparable with the results of other studies from wetlands across Europe (Szymanowska et al. 1999) and also in the Czech Republic (Svobodová et al. 1984; Drbal 1991; Svobodová et al. 1996; 2002; 
Vymazal et al. 2009). On the other hand, we found only few comparable references for the values recorded in great pond snails under natural conditions (Królak 1998). Higher values of studied metals in littoral sediments proved the important role of sediments in their accumulation and also their suitability for heavy metal biomonitoring in fishponds (Svobodová et al. 1996; 2002). Heavy metal concentrations in littoral sediments at all study sites were below the limit values for soil set by the EU for use of sewage sludge in agriculture (CEC 1986). Only in three fishponds in southern Moravia (Pouzdrranský, Mušlovský dolní and Zámecký fishponds) the recorded Cd concentrations reached these limits with more than $1 \mathrm{mg} \cdot \mathrm{kg}^{-1}$ of dry matter. All recorded metal concentration values in reed stems were below its phytotoxic ranges (Roos 1994).

We did not prove the suitability of common reed and great pond snails for metal stress monitoring in ponds, since recorded values in these organisms were not correlated with the values from bottom sediments. Such correlations between metal concentrations in plants, snails and sediments were reported e.g. by Jackson (1998), Szymanowska et al. (1999), Bogatov and Bogatova (2009) or by Bonanno and Lo Giudice (2010), who recommended common reed and pond snails as bioindicators. On the other hand, Drbal (1991) and Svobodová et al. (1996) stated that reed beds are not good metals accumulators compared to other aquatic vegetation types. Similarly to our results, no correlations between metal concentrations in plants, water and soil were recorded by Bragato et al. (2006). On the contrary, higher mercury contents in great pond snails were found at study sites. Inorganic mercury is methylated by microorganisms in bottom sediments into organic compounds (methylmercury), which can be accumulated in food chains. Higher values of mercury were found in tissues of fish and other aquatic organisms, especially those in higher trophic levels (Svobodová et al. 1996). Our findings of high $\mathrm{Hg}$ values in great pond snail tissues $\left(0.017-0.172 \mathrm{mg}^{\cdot \mathrm{kg}^{-1}}\right.$ of dry matter) proved high $\mathrm{Hg}$ accumulation capacity of these molluscs under natural conditions. Thus, this species seems to be a good indicator of mercury stress in fishpond littorals.

In most of studies, bioaccumulation in molluscs was greater than that in fish (Elder and Collins 1991). Also values of metal concentrations in great pond snails recorded during this study were higher than values in common carp tissues recorded by Svobodová et al. (2002) in ponds of South and West Bohemia, whereas metal values for bottom sediments were comparable with our results.

Although direct correlations between the variables of studied fishponds, their surroundings and heavy metal concentrations in littoral components were not recorded, we found some interesting relations between the studied environmental characteristics. As resulted from the performed PCA, lower values of all investigated metals were found in sediments of ponds with larger area of reed beds in their littorals. This finding is probably connected with the buffering efficiency and accumulative characteristics of macrophyte beds that serve as sinks for many elements and nutrients entering pond water bodies (Jackson 1998). These substances can probably stay captured in macrophyte beds and do not come further to pond open water zones. This pattern of macrophyte beds, where besides plants also periphyton, fungi and other microorganisms play an important role (Lakatos et al. 1999), is frequently used in wastewater treatment (Salt et al. 1995). As evidenced by our results, reed beds play a major role in toxic element uptake also in fishponds.

The accumulation capacity of each water body can differ between its various parts. Different heavy metal concentrations were found in shallow sites compared to deeper sites (Pip 2006), in sites near contamination sources compared to relatively unaffected sites (Lakatos et al. 1999; Hassan et al. 2010), in sites with different bedrock characteristic (Pip 2006) or in differently orientated and vegetated sites of the same water body (Chambers and Sidle 1991). Our findings of higher heavy metal values in eastern compared to western parts of studied ponds (significant in $\mathrm{Hg}$ values in reed stems and $\mathrm{Cd}$ 
values in great pond snails) correspond with the direction of prevailing westerly winds at study sites. In favourable conditions, this mostly unidirectional wind flowing can cause a development of extensive reed beds in eastern pond parts, where also strong organic matter accumulation occurs (James et al. 1988). Higher amount of organic matter and nutrients can positively influence metal accumulation both in organisms and sediments (Drbal 1991; Svobodová et al. 1996; Jackson 1998). Similarly, Sidle et al. (1991) referred to higher metal accumulation in sediments in connection with depositional patterns in individual water body and stated that these so-called fluvial processes are for bioaccumulation at least as important as chemical processes. The accumulation of metals in invertebrates is also dependent on functional feeding group and scrapers that feed on periphyton, such as snails, accumulated the largest concentrations of metals (Farag et al. 1998).

The direct influence of the pond surrounding character (the rate of agriculture fields, meadows, woods, motorways etc.) was not proved at study sites. Similarly also Svobodová et al. (1982) did not find any differences in the total mercury contents in biocenoses of fishponds with different watershed character (agricultural, forest, with industrial wastes). On the other hand, Drbal (1991) proved higher metal concentrations in ponds surrounded by agriculture areas and Packard and Evans (2006) in ponds with more urbanized watershed.

The close presence of motorways to the ponds can probably influence some metal input to their littorals (Demirezen and Aksoy 2004). The impact of exhaust emission on the lead content in reed beds near motorways compared to farther reed bed parts was confirmed by Svobodová et al. (1996). However, Svobodová et al. (1984) found no differences between lead concentrations in sediments and invertebrates in fishponds with various distances from motorways. The use of unleaded fuels in the last decades could cause a decrease of lead input to landscape and lead concentrations might not be recently higher along motorways, which also corresponds with our results.

The research of heavy metal contamination in aquatic environments usually focuses on localities with higher heavy metal input caused by nearby sources (e.g., waste from the chemical industry, larger motorways), where higher concentrations of these elements are often proved (Chambers and Sidle 1991; Hassan et al. 2010). The results of this pilot study contribute to the understanding of heavy metal cycles and their accumulation in fishponds under semi-natural conditions and in less affected landscape with agriculture and woodland areas. However, further studies focused in detail on processes related to heavy metal accumulation in particular components of fishpond littoral will be necessary for better evaluation of the anthropogenic load on these ecosystems.

\section{Acknowledgements}

This study was supported by the Ministry of Education of the Czech Republic (projects no. MSM 6215712402 and MSM 0021622416).

\section{References}

Bogatov VV, Bogatova LV 2009: Heavy metal accumulation by freshwater hydrobionts in a mining area in the south of the Russian far east. Russ J Ecol 40: 187-193

Bonanno G, Lo Giudice RL 2010: Heavy metal bioaccumulation by the organs of Phragmites australis (common reed) and their potential use as contamination indicators. Ecol Indic 10: 639-645

Bragato C, Brix H, Malagoli M 2006: Accumulation of nutrients and heavy metals in Phragmites australis (Cav.) Trin. ex Steudel and Bolboschoenus maritimus (L.) Palla in a constructed wetland of the Venice lagoon watershed. Environ Pollut 144: 967-975

Čelechovská O, Malota L, Zima S 2008: Entry of heavy metals into food chains: a 20-year comparison study in northern Moravia (Czech Republic). Acta Vet Brno 77: 645-652

Chambers JC, Sidle RC 1991: Fate of heavy metals in an abandoned lead-zinc tailings pond: I. Vegetation. J Environ Qual 20: 745-751

Council of the European Communities 1986: Council Directive of 12 June 1986 on the protection of the environment, and in particular of the soil, when sewage sludge is used in agriculture. Official J European Communities no. L181, pp. 6-12 
Drbal K 1991: Heavy metals in some parts of the ecosystem of surface waters of south Bohemia. Ecology (CSFR) 10: $327-338$

Elder JF, Collins JJ 1991: Freshwater molluses as indicators of bioavailability and toxicity of metals in surfacewater systems. Rev Environ Contam Toxicol 122: 37-79

ESRI Inc. 2008: ArcMap, version 9.3. License type: ArcInfo. www.esri.com

Farag AM, Woodward DF, Goldstein JN, Brumbaugh W, Meyer JS 1998: Concentrations of metals associated with mining waste in sediments, biofilm, benthic macroinvertebrates, and fish from the Coeur d'Alene River basin, Idaho. Arch Environ Contam Toxicol 34: 119-127

Hassan S, Schmieder K, Böcker R 2010: Spatial patterns of submerged macrophytes and heavy metals in the hypertrophic, contaminated, shallow reservoir Lake Qattieneh/Syria. Limnologica 40: 54-60

Jackson LJ 1998: Paradigms of metal accumulation in rooted aquatic vascular plants. Sci Total Environ 219: $223-231$

James MR, Weatherhead MA, Stanger C, Graynoth E 1988: Macroinvertebrate distribution in the littoral zone of Lake Coleridge, South Island, New Zealand - effects of habitat stability, wind exposure and macrophytes. New Zeal J Mar Fresh 32: 287-305

Królak E 1998: Concentration of heavy metals in the snails Lymnaea (Radix) peregra (O.F. Mull) and Lymnaea stagnalis (L) occurring in rivers near Siedlce town. Pol Arch Hydrobiol 45: 553-563

Lakatos G, Kiss M, Mészáros I 1999: Heavy metal content of common reed (Phragmites australis/Cav./Trin. ex Steudel) and its periphyton in Hungarian shallow standing waters. Hydrobiologia 415: 47-53

Packard HD, Evans MJ 2006: Heavy metal concentrations in lacustrine sediments of developed and undeveloped watersheds, Williamsburg, VA. Philadelphia Annual Meeting, Paper No. 56-58.

Pip E 2006: Littoral mollusc communities and water quality in southern Lake Winnipeg, Manitoba, Canada. Biodivers Conserv 15: 3637-3652

Roos MS 1994: Sources and forms of potentially toxic metals in soil-plant systems. In: Ross MS (ed): Toxic metals in soil--plant system. John Wiley, Chichester, pp. 3-25

Salt DE, Blaylock M, Kumar N, Dushenkov V, Ensley BD, Chet I, Raskin I 1995: Phytoremediation: a novel strategy for the removal of toxic metals from the environment using plants. Nat Biotechnol 13: 468-474

Sidle RC, Chambers JC, Amacher MC 1991: Fate of heavy metals in an abandoned lead-zinc tailings pond: II. Sediment. J Environ Qual 20: 752-758

StatSoft Inc. 2008: Statistica (data analysis software system), version 8.0. http://www.statsoft.com.

Svobodová Z, Hejtmánek M, Faina R, Havlíková J 1982: Obsah celkové rtuti v rybách a v ostatních složkách vodní biocenózy vybraných rybníků. (The content of total mercury in fish and in other constituents of water biocenosis in the selected fishponds). Buletin VÚRH Vodňany 18: 16-20

Svobodová Z, Faina R, Máchová J, Hejtmánek M, Drbal K 1984: Rtut' a olovo v rybách a v rybničním prostředí. (Mercury and lead content in fish and fishpond environment). Acta Hyg Epidemiol Microbiol, Praha, Bratislava, IHE a VÚ prevent. lekár., Supplement 2, 10-15 pp.

Svobodová Z, Máchová J, Vykusová B, Piačka V 1996: Kovy v ekosystémech povrchových vod. (Heavy metals in freshwater ecosystems). VÚRH Vodňany, edice Metodik 49, 18 p.

Svobodová Z, Žlábek V, Čelechovská O, Randák T, Máchová J, Kolářová J 2002: Content of metals in tissues of marketable common carp and in bottom sediments of selected ponds of South and West Bohemia. Czech J Anim Sci 47: 339-350

Szymanowska A, Samecka-Cymerman A, Kempers AJ 1999: Heavy metals in three lakes in west Poland. Ecotox Environ Safe 43: 21-29

ter Braak CJF, Šmilauer P 2002: CANOCO Reference manual and CanoDraw for Windows user's guide: Software for canonical community ordination (version 4.5). Ithaca, NY, USA (www.canoco.com), Microcomputer Power

Vymazal J, Kröpfelová L, Švehla J, Chrastný V, Štíchová J 2009: Trace elements in Phragmites australis growing in constructed wetlands for treatment of municipal wastewater. Ecol Eng 35: 303-309 